\title{
Niniveh and Alexandria: The Two Vanished Libraries of Antiquity
}

\author{
Mariana Borcoman \\ Professor, $\mathrm{PhD}$ \\ Transilvania University of Brasov, \\ Department of Social Sciences and Communication \\ E-mail marianaborcoman@gmail.com
}

\begin{abstract}
Humankind has dramatically evolved for the past thousands of years in terms of communication - starting from signs and signals conveyed via visual and auditory means and ending up with the set of signs that came to be known as the alphabet over a vast geographic area. For example, the Sumerian tablets created in Uruk were initially destined for commercial purposes and it was only afterwards that they were viewed as including knowledge of their time. Another example of historical evolution is the Egyptian papyruses gathered in Alexandria in the greatest building of the ancient world's library. Nowadays there are only few such remnants, but their importance for how writing has evolved is invaluable.
\end{abstract}

Keywords: library; papyrus; tablets; general catalogue; inventory

\section{Introduction}

For the people of the XXI century, access to technology has become a habit. Thus, consulting information via the Internet, rapid communication through socialization networks, access to digital libraries, or instant texting are some of our daily activities and it is more than normal to consider them as a sign of evolution. Nonetheless, such means of writing and communication among communities have taken years of creation and refining.

Social communication has been one of humans' main features for thousands of years. As Erich (2008, p. 5) states, "In the beginning, the knots on the string, the sticks or stones of various shapes and sizes expressed in a material form the word. Subsequently, people have discovered the visual art of rendering the oral word with the help of the figure or beings to which it refers" [1]. Therefore, the forms of communication are different and have evolved over time - starting with acoustic and vocal signs, moving on to the tally system or to objects strung on a rope, the first letters that are precursors of the alphabet and ending with the use of the Internet and communication via emails.

Books are the tell tale of how valuable an author is and also of a community. Books as commodity used to be highly expensive and their value was measured in cattle or land - which were the exchange means for communities in the Ancient world and the Middle Ages. Writing and reading skills were only acquired by initiated people in Antiquity and then by aristocracy in the Middle Ages. It is only with modern times that they have become part of mass culture as a result of state involvement in establishing elementary schools. In this respect, our article focuses on two great libraries of Antiquity that used to be emblematic for the Mediterranean area given the latter's development generated by the commerce with merchandise, slaves and texts.

\section{The history of the Assyrian library}

The Ancient East was the cradle of the oldest civilizations and the fit area for state crystallization.

Revista Română de Biblioteconomie şi Ştiința Informării = Romanian Journal of Library and Information Science ISSN 2559-5490, ISSN-L 1841-1940 • Volume 13 Issue 42017 pp. 109-112 https://doi.org/10.26660/rrbsi.2017.13.4.109

This work is licensed under a Creative Commons Attribution-NonCommercial-NoDerivatives 4.0 International License 
Kingdoms and empires like Sumer, Assyria, Babylon and Egypt emerged between the Tigris and Euphrates, and on the banks of the Ganges or the Nile. The state was supported by well organized political and administrative systems along with well paid armies. With the prosperity of economies and state expansion the concern for the arts also emerged. The priests were the ones guarding spiritual life and faith in gods - important coordinates that managed to keep population under the control of political power. Writing emerged as a result of priests' and kings' concern for it and was honed through penmen's hard work. Initially it was but a small number of signs destined for a small group of people that afterwards spread over large areas. Writing on soft clay tablets or papyrus was part of the Mesopotamian and Egyptian cultures and these were the foundation for the most well known library during the Antiquity, namely the one raised in Niniveh.

Traces of Sumerian writings were identified in the old Lagaš in 1877 when statues and old writings were discovered. The oldest writings were no different from the pictographs of the previous age and they represented the foundation for Sumerian writing. The Sumerian vocabulary was characteristic of an agglutinative language - impressions of straight lines or circles on soft clay were made using reed or wooden stylus. Penmen were the ones who created the clay tablets and their cuneiform writing was only known by a group of initiates.

The library was established by the Neo Assyrian King Ashurbanipal - a man of vision since he gathered the scholars of his time in his court. The latter copied manuscripts from different areas of the empire, including Babylonian, Greek and even Hebrew texts. Clay tablets were used for writing and the impression was made with a sharp tool (a stylus employed on the soft clay tablets that afterwards were burnt in ovens) that actually gave the name of the writing - cuneiform. The texts in the library inventory were old, dating back to the VII century B.C. and included the literary master piece of the East, namely the Epic of Gilgamesh, the most famous Babylonian creation, "a dramatic illustration of human condition defined by the impossibility to avoid death" [2] (Eliade, 1991, p. 87). The Epic of Gilgamesh was the greatest literary work of the time and it was written on twelve tablets. It describes the confrontation between a mortal and the powerful goddess Ishtar and the search for a cure for death. Another work in the library was the so-called Venus Tablet - a collection of astronomical texts and observations of Venus planet's movement for a 21 years time period.

The secondary information available today indicates that the inventory of this royal library contained 30,000 tablets and fragments at the time of its destruction. The texts on the tablets were of various sorts: administrative, legal, diplomatic, commercial, spiritual like prophecies, incantations, hymns to gods or synthetic works such as medical, astronomical treaties or even literary works. The library had more than twelve rooms and the tablets were thematically organized, while a small inventory was to be found in front of every room. All this was included in the general inventory of the library.

Most of the tablets in the library were destroyed in 612 B.C. by the Medes who came from the North of Mesopotamia and looted and then controlled the Assyrian kingdom.

The rest of tablets that survived fires and looting were discovered by a British archaeologist, Ansten Henry Layard, in the North of Mesopotamia, in Kouyunjik, close to nowadays' Mosul Iraq. They were taken to London and they are exhibited in the British Museum.

\section{The History of the Library in Alexandria}

History provides numerous examples of personalities who conquered vats territories and were also cultivated people with a high esteem for art. A famous example in this respect is Alexander the Great, the young king of Macedonia who conquered most of Southern Europe and Central Asia and his armies even made it to India. He was a visionary and courageous king who founded the greatest empire ever known in history. During his childhood and teenage years he was a disciple of 
Aristotle and of the Greek philosophy school. As a result, he learnt philosophy, acquired oratorical and analytical skills and mastered tolerance. These qualities helped him become a great leader and made him receptive to the culture of the peoples he encountered in the wars he waged.

The city of Alexandria was founded by Alexander the Great during his conquests in Egypt. He planned to build a great cultural establishment but he died young before accomplishing that. His plan was seen to fruition by the Pharaoh Ptolemy II Soter who established the library in 283 B.C. it was solid construction that was part of a city where all building were made of stone (a great effort considering the great distances from where stone was brought). The real library organizer was Demetrius, former governor of Athens, who had left the city for political reasons and chose to work for Ptolemy II. The latter offered him a peaceful life and tasked him with the complex activity or organizing the library. By the Pharaoh's order, many art lovers, philosophers, sculptures and cultivated people gathered around the Museion library in the city. Demetrius organized the library, its general catalogue and the catalogues for each section of the library. The papyruses were thematically organized in separate rooms and they were inventoried in a catalogues to be found in front of every room.

The library hosted penmen who translated and copied texts from Greek and Hebrew as accurately as possible. The building of the library was extremely large for those times and hosted 700,000 volumes, study and conference rooms. The texts were written on papyrus and the latter was manufactured by the method employed in the $3^{\text {rd }}$ millennium B.C. - the plant, similar to the reed, would be smashed in stalks and these would be sewn one to another resulting a piece of paper suitable for writing. Its length could even reach $12 \mathrm{~m}$ and it was rolled on bamboo sticks to make their preservation easier.

The poet Callimachus of Cyrene, who worked in the library of Alexandria elaborated the first methodical catalogue of the Greek writers, known by the name of pinakes. The latter provided information on writings and their circulation in the Mediterranean area.

The library was destroyed in two stages. During the civil war between Pompey and Caesar, the latter's troop burnt Alexandria and its library to the ground since Pompey had taken shelter in the city. At the end of the civil war, Caesar becomes the sole ruler and then Roman emperor. The final destruction of the library occurred during Caliph Umar's reign when Arabs reach Alexandria and during their looting burn the remaining papyruses as heretic and contrary to the Quran.

\section{Conclusions}

The information on these two vanished libraries help us create an image. The Antiquity and the two states that were so much politically developed are images of a productive historical period. The works of Greek and Jewish writers circulated across a vast area and were brought by merchants or people paid by the kings to this end. The organization of the two libraries, their vast spaces, thematic rooms, and inventories for each room, as well as their general catalogues are tell tale signs of thorough and methodical work. They are also the result of considerable economic efforts that could only have been made by a stable and politically prosperous state. Scholars worked and studied quietly in Niniveh and Alexandria and it took them tens or hundreds of years to gather the libraries' collections of texts consisting of thousands of samples. History and the power of newcomers led to looting and burning the two wonders of the Ancient East. The partial information glimpsed from secondary sources and the few archaeological pieces that are still available nowadays make us conclude that the two libraries are representative for a time when writings were appreciated, used and stored in building destined to this end. The two ancient libraries are a starting point in the evolution of libraries. They are also landmarks and symbols for what buildings meant to host libraries should be like. 


\section{Notes}

1. Romanian version: „La începuturi nodurile pe sfoară, bețigașele sau pietrele de diverse forme și dimensiuni exprimau într-o formă materială cuvântul. Ulterior oamenii au descoperit arta vizuală de a reda cuvântul oral cu ajutorul figurii sau ființei la care se făcea referire".

2. Romanian version: „O ilustrare dramatică a condiției urmane, definită prin inevitabilitatea morții”.

\section{References}

Eliade, M. (1991) Istoria ideilor și credințelor religioase [History of Religious Ideas], vol. I, București: Editura Științifică.

Erich, A. (2008) Istoria cărții de la semnele mnemotehnice la cartea electronică [The history of books from the mnemotechnical signs to the electronic book], Târgoviște: Editura Bibliotheca.

Olteanu, V. (1992) Din istoria și arta cărții [On the history and art of books], București: Editura Lexicon. 